\title{
Reactivation of Apolipoprotein II Gene Transcription by Cycloheximide Reveals Two Steps in the Deactivation of Estrogen Receptor-Mediated Transcription
}

\author{
MARTHA G. SENSEL, ${ }^{1}$ ROBERTA BINDER, ${ }^{1} \dagger$ CATHERINE B. LAZIER, ${ }^{2}$ AND DAVID L. WILLIAMS ${ }^{1 *}$ \\ Department of Pharmacological Sciences, State University of New York at Stony Brook, Stony Brook, \\ New York 11794-8651, ${ }^{1}$ and Biochemistry Department, Dalhousie University, \\ Halifax, Nova Scotia B3H 4H7, Canada ${ }^{2}$
}

Received 24 November 1993/Accepted 8 December 1993

\begin{abstract}
In this report, we describe apolipoprotein II (apoII) gene expression in cell lines derived by stable expression of the chicken estrogen receptor in LMH chicken hepatoma cells. In cell lines expressing high levels of receptor (LMH/2A), apoII gene expression is increased by estrogen 300-fold compared with levels in the receptordeficient parent LMH line. LMH/2A cells show apoII mRNA induction and turnover kinetics similar to those in chicken liver. Inhibition of protein synthesis with cycloheximide (CHX) or puromycin following estrogen withdrawal superinduces apoII mRNA without affecting apoII mRNA stability. Superinduction is due to an estrogen-independent reactivation of apoII gene transcription. The apoII gene can be reactivated by $\mathrm{CHX}$ for up to $24 \mathrm{~h}$ following hormone withdrawal, suggesting that the gene is in a repressed yet transcriptionally competent state. These results reveal two distinct events necessary for termination of estrogen receptormediated transcription. The first event, removal of hormone, is sufficient to stop transcription when translation is ongoing. The second event is revealed by the CHX-induced superinduction of apolI mRNA following hormone withdrawal. This superinduction suggests that deactivation of estrogen receptor-mediated transcription requires a labile protein. Furthermore, reactivation of apoII gene expression by $\mathrm{CHX}$ and estrogen is additive, suggesting that estrogen is unable to overcome repression completely. Thus, a labile protein may act to repress estrogen receptor-mediated transcription of the apoII gene.
\end{abstract}

In avian liver, estrogens regulate the expression of a number of egg yolk precursor proteins required for the transport of nutrients to the developing oocyte (5). Among the proteins regulated by estrogen are vitellogenin I (VTGI), VTGII, and VTGIII $(63,64)$, apolipoprotein B (apoB) (17) and apoII (18) of very low density lipoprotein, and riboflavin- and biotinbinding proteins $(16,66)$. The primary action of estrogen is to increase transcription of the genes encoding these proteins via binding to the estrogen receptor. In addition to regulating transcription, estrogen also alters the cytoplasmic stability of apoII and VTGII mRNAs $(30,71)$. Analysis of the mechanisms of transcriptional regulation of these genes as well as the study of mRNA turnover in avian liver cells has been hampered by the absence of a suitable homologous cell line. Studies of gene activation and estrogen-dependent alterations in chromatin structure and DNA methylation patterns have been restricted to animal studies or tissue homogenates $(2,3$, $14,15,38,42,67,68)$. Similarly, transcriptional analysis with gene transfer techniques has been limited to transient assays in primary liver cultures or heterologous cell lines $(4,13,56)$. The LMH cell line is a chicken hepatoma that expresses many hepatocyte properties (41) and may provide a homologous cell line for studies of avian liver gene expression. We showed previously that the endogenous apolI gene was expressed in

* Corresponding author. Mailing address: Department of Pharmacological Sciences, State University of New York Health Sciences Center, Stony Brook, NY 11794-8651. Phone: (516) 444-3078. Fax: (516) 444-3218. Electronic mail address: dave@pharm.sunysb.edu.

† Present address: Cell Biology and Metabolism Branch, National Institute of Child Health and Human Development, Bethesda, MD 20892.
LMH cells in response to estrogen; however, the level of response was only $0.1 \%$ of that seen in rooster liver (9). A transfected apoII gene also was expressed in LMH cells, but its expression was dependent on cotransfection with an estrogen receptor expression vector. This finding suggested that the estrogen responsiveness of the LMH cell may be limited by the content of functional estrogen receptor. Consistent with this possibility, receptor binding activity was very low in LMH cells but was detected following transient transfection with vector encoding the receptor. Although the LMH cell has proved useful for promoter analysis of transfected VTGII and apoII genes $(6,9)$, the low level of endogenous apoII mRNA expression limits its usefulness for analyzing various aspects of hormone-dependent gene activation or for studies of mRNA turnover.

In this report, we describe cell lines derived from the LMH line by stable expression of the chicken estrogen receptor. In cell lines expressing high levels of receptor, expression of the endogenous apoII gene is induced strongly by estrogen. Analysis of the $\mathrm{LMH} / 2 \mathrm{~A}$ line shows mRNA induction and turnover kinetics similar to those in chicken liver. The $\mathrm{LMH} / 2 \mathrm{~A}$ line was used to study the effects of inhibiting protein synthesis on apoII gene expression and mRNA turnover following hormone withdrawal. Inhibition of protein synthesis following hormone withdrawal superinduced apoII mRNA by an estrogen-independent reactivation of apoII gene transcription without affecting apoII mRNA stability. These results suggest that removal of hormone is not itself sufficient to terminate expression of the apoII gene. Deactivation of hormone-induced expression may involve a labile protein factor that represses gene expression when estrogen is withdrawn. Thus, these 
results define two steps in the deactivation of estrogen receptor-mediated transcription of the apoII gene.

\section{MATERIALS AND METHODS}

Cell culture. LMH cells (41) were maintained in Waymouth's MB 752/1 without phenol red supplemented with penicillin $(100 \mathrm{U} / \mathrm{ml})$, streptomycin sulfate $(100 \mu \mathrm{g} / \mathrm{ml})$, and $10 \%$ fetal bovine serum (complete medium). Rich Waymouth's medium for transfection experiments was prepared by adding $10 \% \mathrm{LMH}$ conditioned medium, $5 \%$ chicken serum, and $1 \times$ minimal essential medium-vitamin mix to complete Waymouth's media. Cells were grown in T-75 flasks or 60-mmdiameter dishes precoated with $0.1 \%$ gelatin. Typically, cells were cultured for 7 days following plating; medium was changed on day 4 , and hormone was added on day 7. 17 $\beta$ Estradiol and moxestrol [R2858; 11 $\beta$-methoxy-19-nor-17 $\alpha$ pregna-1,3,5(10)-trien-20-yne-3,17-diol; Roussel-UCLAF; obtained from New England Nuclear] were dissolved in ethanol. For hormone withdrawal, medium was aspirated, cells were rinsed with phosphate-buffered saline, and complete hormonefree medium was added. For inhibition of protein synthesis, cells were treated for the indicated times with either cycloheximide $(\mathrm{CHX} ; 2.5 \mu \mathrm{g} / \mathrm{ml})$ or puromycin $(100 \mu \mathrm{g} / \mathrm{ml})$ dissolved in Waymouth's medium.

Stable transfection with chicken estrogen receptor. Chicken estrogen receptor plasmids pCEO (43) and pRSVCEO (12a), driven by the simian virus 40 promoter and the Rous sarcoma virus promoter, respectively, were cotransfected with plasmid pRSVNEO (31), which confers G418 resistance. Stably transfected lines were established by the modified calcium phosphate method (19). Transfection was performed 1 day after plating, using $3 \mu \mathrm{g}$ of selection plasmid and $27 \mu \mathrm{g}$ of estrogen receptor plasmid. Following overnight incubation in $3 \% \mathrm{CO}_{2-}$ $97 \%$ air, cells were transferred to rich medium and incubated in an atmosphere of $5 \% \mathrm{CO}_{2}-95 \%$ air for 3 days prior to selection in rich medium containing $100 \mu \mathrm{g}$ of G418 per ml. Colonies were visible after 14 days in selection. Cell lines were then maintained in complete Waymouth's medium without G418.

RNA isolation and analysis. Total RNA was isolated by the guanidine isothiocyanate method (20) followed by extraction with phenol. For some experiments, RNA was isolated by the single-step acid-guanidinium thiocyanate-phenol method (21), either as originally described or with RNASTAT (Tel-Test "B", Inc., Friendswood, Tex.). Nuclear and cytoplasmic RNAs were prepared as described previously (29) except that cell pellets were lysed in $4 \mathrm{ml}$ of buffer $(0.5 \%$ Nonidet P- $40,10 \mathrm{mM}$ $\mathrm{NaCl}, 3 \mathrm{mM} \mathrm{MgCl} 2,10 \mathrm{mM}$ Tris- $\mathrm{HCl}$ [pH 7.4]), incubated on ice for $10 \mathrm{~min}$, and centrifuged for $5 \mathrm{~min}$ at $1,000 \times \mathrm{g}$. The supernatant was transferred to a sterile tube, and vanadylribonucleoside complex $(10 \mathrm{mM})$ was added prior to isolation of cytoplasmic RNA. The nuclear pellet was washed with lysis buffer to remove contaminating cellular debris, and nuclear RNA was isolated by guanidinium isothiocyanate extraction as described above. For Northern (RNA) blot analysis, RNA was fractionated through a $1.2 \%$ agarose- $6 \%$ formaldehyde gel, electroblotted to Nytran (Schleicher \& Schuell), and crosslinked with UV light (Stratalinker; Stratagene). RNA gels were stained with ethidium bromide to ensure that samples contained equal amounts of RNA. Blots were hybridized with random-primed probes (Prime-It; Stratagene) prepared from the genomic chicken apoII clone pApo107 (12a), the chicken transferrin cDNA clone pCon64 (23), the chicken glyceraldehyde phosphate dehydrogenase (GAPDH) clone pGAD28
(27), and the chicken estrogen receptor clone pCEO as described in the figure legends, by using standard conditions.

Nuclear run-on transcription assays were carried out essentially as described previously (33). For each treatment, nuclei were pooled from dishes of cells cultured as described above. The final radiolabeled RNA pellet was resuspended in $2.0 \mathrm{ml}$ of $N$-tris(hydroxymethyl)methyl-2-aminoethanesulfonic acid (TES) buffer (10 mM EDTA, $0.2 \%$ sodium dodecyl sulfate [SDS], $10 \mathrm{mM}$ TES [pH 7.4]), and duplicate 5- $\mu$ l aliquots were precipitated in $7.5 \%$ trichloroacetic acid for $15 \mathrm{~min}$ on ice. Precipitated RNA was collected onto glass fiber filters (Whatman), and incorporated radionucleotide was quantified by scintillation counting. Equivalent counts of radiolabeled RNA (see figure legends) from each treatment group were hybridized to Nytran strips containing dot blots of linearized and sodium hydroxide-denatured plasmid DNA containing the gene or cDNA of interest. Ethidium bromide $(0.5 \mu \mathrm{g} / \mathrm{ml})$ was added to DNA for dot blots, and bound DNA was visualized by UV light to ensure that equivalent amounts of DNA were blotted. Blotted DNA was cross-linked with UV light (Stratalinker) and dried for $15 \mathrm{~min}$ at $65^{\circ} \mathrm{C}$. Blots were incubated in TES- $\mathrm{NaCl}(300 \mathrm{mM} \mathrm{NaCl}, 10 \mathrm{mM}$ EDTA, $0.2 \%$ SDS, $10 \mathrm{mM}$ TES [pH 7.4]) for $2 \mathrm{~h}$ at $65^{\circ} \mathrm{C}$ and hybridized with radiolabeled RNA in TES- $\mathrm{NaCl}$ at $65^{\circ} \mathrm{C}$ for $40 \mathrm{~h}$. Samples were washed in $5 \mathrm{ml}$ of $2 \times \mathrm{SSC}(1 \times \mathrm{SSC}$ is $0.15 \mathrm{M} \mathrm{NaCl}$ plus $0.015 \mathrm{M}$ sodium citrate) for $1 \mathrm{~h}$ at $65^{\circ} \mathrm{C}$, treated with RNase $\mathrm{A}(10 \mu \mathrm{g} / \mathrm{ml})$ for 30 min at $37^{\circ} \mathrm{C}$, and washed in $2 \times \mathrm{SSC}$ at $65^{\circ} \mathrm{C}$ for $1 \mathrm{~h}$. Plasmid DNAs used for detection of specific RNAs included pApo107, pUC8, pGAD28, pCon64, and pA1 containing the chicken $\beta$-actin cDNA (22).

DNA-excess solution hybridization was carried out as described previously $(30,69)$, using a probe containing nucleotides 210 to 449 of the apoII cDNA (57). RNA probe-excess solution hybridization assays used plasmid pBSapoII.240, containing the same fragment subcloned into Bluescript $\mathrm{SK} / \mathrm{KS}+$ (Stratagene). ${ }^{32} \mathrm{P}$-labeled antisense apoII RNA was transcribed in vitro by T7 RNA polymerase on a Bam HI-linearized pBSapoII.240 template. For use as a standard curve, ${ }^{3} \mathrm{H}$ labeled sense strand was synthesized by T3 RNA polymerase on a HindIII-linearized template. Hybridization was carried out in $0.3 \mathrm{M} \mathrm{NaCl}-30 \mathrm{mM}$ sodium citrate $(\mathrm{pH} \mathrm{7.0)}$ for $18 \mathrm{~h}$ at $68^{\circ} \mathrm{C}$. Samples were treated with RNase $T_{1}(500 \mathrm{U} / \mathrm{ml})$ and RNase A $(40 \mu \mathrm{g} / \mathrm{ml})$ at $55^{\circ} \mathrm{C}$ for $1 \mathrm{~h}$, precipitated with trichloroacetic acid (7.5\%), collected on glass fiber filters, and counted by liquid scintillation spectrometry. Data from solution hybridization assays are expressed as picograms of apoII mRNA per microgram of total RNA.

Measurement of mRNA half-life. ApoII mRNA half-life was determined during hormone induction by approach-to-steadystate analysis $(7,65)$. ApoII mRNA half-life in the absence of hormone was determined directly by semilogarithmic analysis of apoII mRNA decay in hormone-withdrawn cells. Half-life $\left(t_{1 / 2}\right)$ was calculated from the slope of the regression line, using the equation $t_{1 / 2}=\ln 2 / k$, where slope $=-k$.

Measurement of estrogen receptor. Estrogen receptor binding site concentration and equilibrium dissociation constants were determined for nuclear, cytoplasmic, microsomal, and whole cell extracts of $\mathrm{LMH} / 2 \mathrm{~A}$ cells by Scatchard analysis of ligand binding data. Ligand binding assays were carried out as described previously (45) except that homogenization buffer was that used by Green et al. (32). Labeling with [ring${ }^{3} \mathrm{H}$ ] tamoxifen aziridine was carried out as described previously (40). 
A

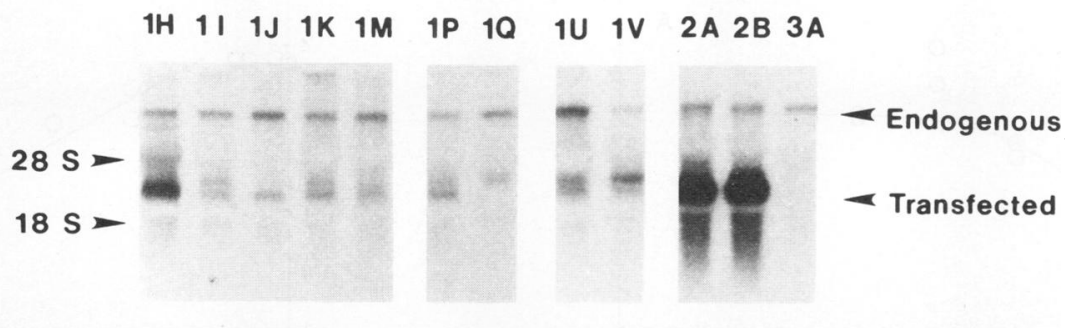

B

\begin{tabular}{|c|c|c|c|}
\hline \multirow[b]{2}{*}{ CLONE } & $50 \mathrm{nM}$ Estrogen & Ethanol & \multirow[b]{2}{*}{ Receptor mRNA Level } \\
\hline & $\mathrm{pg}$ apoII $/ \mu \mathrm{g}$ RNA & $\mathrm{pg}$ apolI/ $\mu \mathrm{g}$ RNA & \\
\hline $1 \mathrm{U}$ pCEO & 0.024 & 0.005 & ++ \\
\hline $1 \mathrm{P} n$ & 0.048 & 0 & ++ \\
\hline $1 \mathrm{M} "$ & 0.059 & 0.013 & + \\
\hline $1 \mathrm{~J} "$ & 0.118 & 0 & + \\
\hline $1 \mathrm{~V} "$ & 0.123 & 0.038 & ++ \\
\hline $1 Q "$ & 0.166 & 0 & + \\
\hline $11 "$ & 0.229 & 0 & ++ \\
\hline $1 \mathrm{~K} "$ & 0.308 & 0.005 & ++ \\
\hline $1 \mathrm{H} \quad "$ & 0.941 & 0 & +++ \\
\hline 2A pRSVCEO & 19.79 & 0.681 & ++++ \\
\hline $2 \mathrm{~B}^{n}$ & 20.41 & 0.968 & ++++ \\
\hline $2 F^{n}$ & 24.26 & 1.11 & ++++ \\
\hline $2 \mathrm{E}^{n}$ & 33.75 & 1.69 & ++++ \\
\hline (Liver & 400) & & \\
\hline
\end{tabular}

FIG. 1. Induction of endogenous apoII mRNA in LMH cells stably transfected with the chicken estrogen receptor. (A) Northern analysis of estrogen receptor mRNA in stable cell lines. Total RNA $(10 \mu \mathrm{g})$ was probed for estrogen receptor with an EcoRI fragment of pCEO as described in Materials and Methods. Cell lines resulting from transfection with pCEO, pRSVCEO, and pUC8 (negative control) are designated by 1,2 , and 3 , respectively. Transfected $(2.3-\mathrm{kb})$ and endogenous $(7.5-\mathrm{kb})$ receptor mRNAs are indicated by arrows. (B) Induction of apoII mRNA in LMH stable cell lines. Cells were harvested following incubation for $24 \mathrm{~h}$ in medium containing $50 \mathrm{nM}$ 173-estradiol or ethanol. ApoII mRNA was quantified by DNA-excess solution hybridization. Each value represents the average of duplicate samples. Cell lines correspond to those in panel A. Two lines not represented in panel A, $2 \mathrm{E}$ and $2 \mathrm{~F}$, are also included. Relative levels of estrogen receptor mRNA determined by Northern analysis in panel A are indicated by one or more plus signs for cell lines in panel B.

\section{RESULTS}

Establishment of cell lines that stably express functional chicken estrogen receptor. LMH cells were transfected with pRSVNEO together with either pCEO or pRSVCEO as described in Materials and Methods. Colonies resistant to G418 were expanded into independent lines and screened for expression of chicken estrogen receptor. Transfection of cells with pCEO and pRSVNEO resulted in 31 G418-resistant lines, and 14 clones were positive for expression of chicken estrogen receptor mRNA as determined by Northern blot analysis. Transfection of cells with pRSVCEO and pRSVNEO yielded seven G418-resistant lines, and four lines were positive for estrogen receptor mRNA. Representative clones are shown in Fig. 1A. Relative abundance of estrogen receptor mRNA was greater for the $\mathrm{LMH} / 2$ lines transfected with pRSVCEO than for the $\mathrm{LMH} / 1$ lines transfected with pCEO (compare lanes $2 \mathrm{~A}$ and $2 \mathrm{~B}$ with lanes $1 \mathrm{H}$ to $1 \mathrm{~V}$ ). Clones positive for expression of estrogen receptor mRNA were assayed for apoII mRNA by probe-excess solution hybridization following treatment with $50 \mathrm{nM} 17 \beta$-estradiol. Levels of apoII mRNA and estrogen receptor mRNA correlated roughly (Fig. 1B), confirming the dependence of apoII expression on functional estrogen receptor. Clonal lines $\mathrm{LMH} / 2 \mathrm{~A}, \mathrm{LMH} / 2 \mathrm{~B}, \mathrm{LMH} / 2 \mathrm{E}$, and $\mathrm{LMH} / 2 \mathrm{~F}$ expressed apoII mRNA at levels of 20 to $35 \mathrm{pg} / \mu \mathrm{g}$ (Fig. 1B). In additional experiments carried out under optimal induction conditions, the estrogen-induced $\mathrm{LMH} / 2 \mathrm{~A}$ and $\mathrm{LMH} / 2 \mathrm{E}$ lines expressed apoII mRNA at levels of 30 to 40 and 60 to $80 \mathrm{pg} / \mu \mathrm{g}$, respectively. These levels are 10 to $20 \%$ of the apoII mRNA level in estrogen-induced rooster liver. Furthermore, this induction is more than 300 -fold higher than the maximal level $(0.065 \mathrm{pg} / \mu \mathrm{g}$ ) observed in the parent LMH line (data not shown). One clonal line, LMH/2A, was selected for further investigation.

Estrogen receptor level in LMH/2A cells. Estrogen receptor levels in extracts from $\mathrm{LMH} / 2 \mathrm{~A}$ cells treated with $17 \beta$-estradiol were determined by a ligand binding assay as described in 

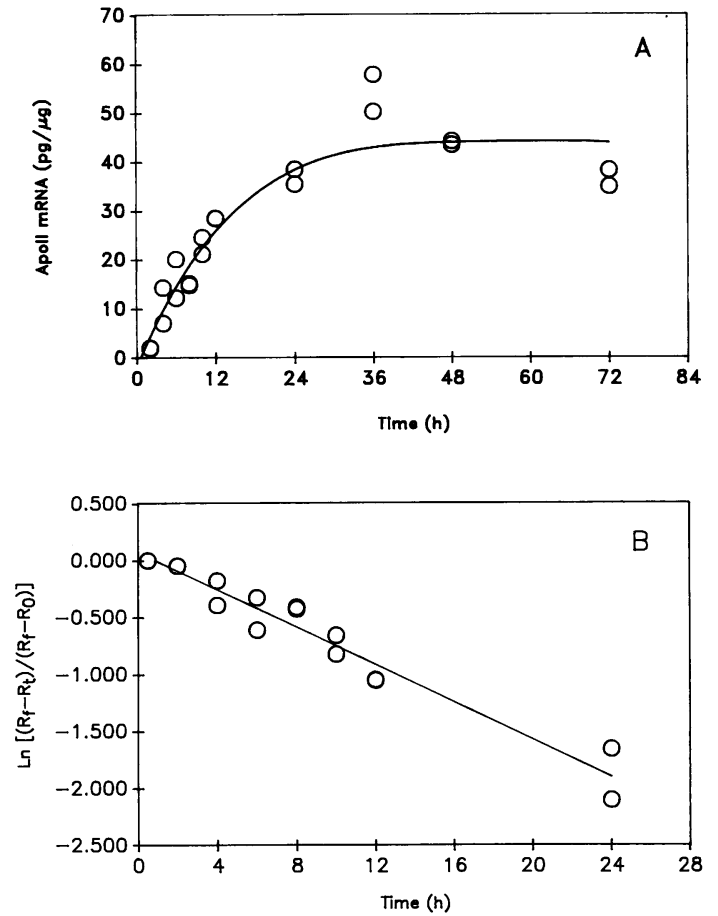

FIG. 2. ApoII mRNA half-life following hormonal induction. $\mathrm{LMH} / 2 \mathrm{~A}$ cells were cultured as described in Materials and Methods. Cells were treated with $50 \mathrm{nM}$ moxestrol for 0 to $72 \mathrm{~h}$, and apolI mRNA was analyzed by DNA-excess solution hybridization. (A) ApoII mRNA expression versus time. Each point represents a pool of two dishes. (B) Approach-to-steady-state analysis. The ascending portion of the curve in panel A was replotted by the method of Watson et al. (65). Half-life was calculated from the slope of the regression line, using the equation $t_{1 / 2}=\ln 2 / k$, where slope $=-k$.

Materials and Methods. Receptor was detected in cytosolic and microsomal fractions (697 and $725 \mathrm{fmol}$ of receptor per $\mathrm{mg}$ of protein, respectively), but the highest concentration was found in nuclear extracts. The concentration of nuclear estrogen receptor in $\mathrm{LMH} / 2 \mathrm{~A}$ cells was sixfold higher than the concentration in estrogen-induced immature chick liver nuclei assayed simultaneously $(6,200$ versus $1,000 \mathrm{fmol}$ of receptor per mg of protein). These $\mathrm{LMH} / 2 \mathrm{~A}$ estrogen receptor levels are 150 -fold greater than levels in $\mathrm{LMH}$ parent cells $(<40$ $\mathrm{fmol} / \mathrm{mg}$ of protein, nuclear; $<5 \mathrm{fmol} / \mathrm{mg}$ of protein, cytosolic) and 25-fold greater than levels in LMH cells transiently transfected with pCEO $(260 \mathrm{fmol} / \mathrm{mg}$ of protein, nuclear; 36 $\mathrm{fmol} / \mathrm{mg}$ of protein, cytosolic), as described previously (9). Scatchard analysis predicted a dissociation constant of $2.36 \mathrm{nM}$ for nuclear receptors (data not shown). Nuclear estrogen receptor, examined by SDS-polyacrylamide gel electrophoresis after $\left[{ }^{3} \mathrm{H}\right]$ tamoxifen aziridine labeling of nuclear extracts, migrated with the expected molecular size of $64 \mathrm{kDa}$ (data not shown). Thus, $\mathrm{LMH} / 2 \mathrm{~A}$ cells express functional estrogen receptor at levels markedly greater than those in estrogentreated rooster liver and $\mathrm{LMH}$ parent cells.

ApoII mRNA induction and turnover in LMH/2A cells. $\mathrm{LMH} / 2 \mathrm{~A}$ cells were induced with the synthetic estrogen moxestrol in order to characterize apoII mRNA expression. Moxestrol was chosen because of its slower metabolism compared with $17 \beta$-estradiol (51). Treatment of cells with $50 \mathrm{nM}$ moxestrol for $24 \mathrm{~h}$ yielded maximal ( 30 to $40 \mathrm{pg} / \mu \mathrm{g}$ ) apoII mRNA levels (data not shown). Time courses of apoII mRNA induc-

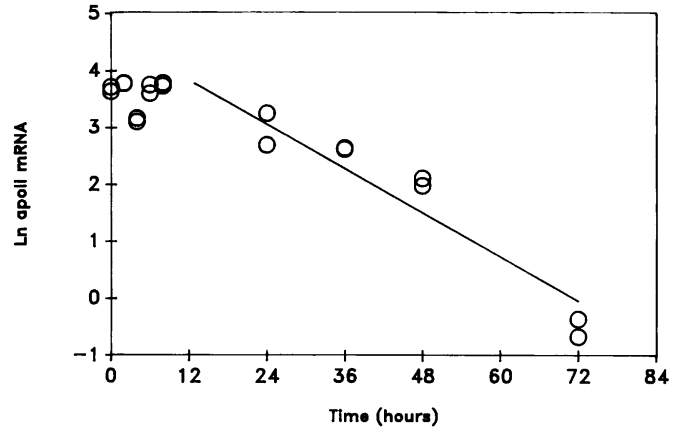

FIG. 3. ApoII mRNA half-life following hormone withdrawal. $\mathrm{LMH} / 2 \mathrm{~A}$ cells were cultured as described in Materials and Methods. Moxestrol $(50 \mathrm{nM})$ was added for $24 \mathrm{~h}$, and cells were withdrawn from hormone for 0 to $72 \mathrm{~h}$. ApoII mRNA was analyzed by DNA-excess solution hybridization. Each point represents a pool of two dishes. Half-life was calculated from the slope of the regression line, using the equation $t_{1 / 2}=\ln 2 / k$, where slope $=-k$.

tion and withdrawal were carried out to determine apoII mRNA half-life in $\mathrm{LMH} / 2 \mathrm{~A}$ cells. Half-life during hormone induction from 0 to $72 \mathrm{~h}$ was determined by approach-tosteady-state analysis $(7,65)$. This analysis yielded a first-order decay constant of $0.082 \mathrm{~h}^{-1}$ and a $t_{1 / 2}$ of $8.4 \mathrm{~h}$ (Fig. 2). This decay rate is consistent with but slightly faster than the half-life of $12 \mathrm{~h}$ reported for apoII mRNA in rooster liver (30).

ApoII mRNA half-life following withdrawal from hormone was determined directly by analysis of apoII mRNA remaining at various times after induction and removal of hormone. Under these conditions, apoII mRNA decayed after an initial lag period of approximately $8 \mathrm{~h}$ following hormone withdrawal (Fig. 3). Therefore, half-life was determined in the 8- to 72-h time interval, yielding a value of $10.7 \mathrm{~h}$. In subsequent experiments, apoII mRNA half-life varied between 9 and $11 \mathrm{~h}$. These results are consistent with the 8.4-h half-life determined by the approach-to-steady-state analysis.

To determine whether the lag time in apoII mRNA decay was due to residual transcription, the estrogen receptor antagonist 4-hydroxytamoxifen was added to cells during hormone withdrawal. In avian cells, tamoxifen and its metabolite 4-hydroxytamoxifen are potent antagonists of estrogen action that act by competitively inhibiting the binding of estrogens to the estrogen receptor $(11,60,61)$. Tamoxifen also rapidly reverses the estrogen-dependent induction of apoII synthesis and apoII mRNA in chick liver $(10,30)$. For the current experiments, the concentration of 4-hydroxytamoxifen used (1 $\mu \mathrm{M})$ was sufficient to block moxestrol-induced apoII mRNA expression. Addition of 4-hydroxytamoxifen had little or no effect on apolI half-life in several experiments and did not affect the apparent lag time for mRNA decay (data not shown). Thus, residual transcription of the apoII gene is unlikely to account for the lag period. This conclusion is supported by the finding that both intron A-containing nuclear apoII mRNA precursors and transcription of the apoII gene are near background levels by $8 \mathrm{~h}$ after hormone withdrawal (see Fig. 6 and 7).

The data presented above suggest that apoII mRNA expression in the $\mathrm{LMH} / 2 \mathrm{~A}$ cell line is similar to that observed in estrogen-treated liver. The kinetics of induction and decay are similar but slightly faster than those reported in rooster liver. Thus, this cell line provides a useful model for investigating mechanisms involved in apoII mRNA turnover.

Effect of inhibiting protein synthesis on apoII mRNA turnover. Inhibition of protein synthesis has been shown to either 

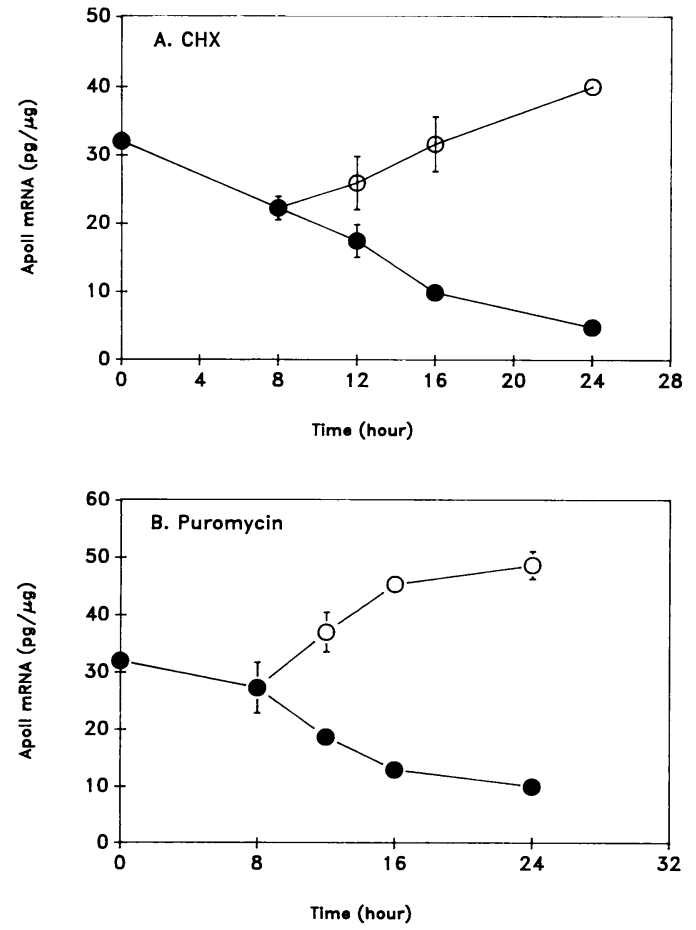

FIG. 4. Effects of $\mathrm{CHX}$ and puromycin on apoII mRNA turnover. $\mathrm{LMH} / 2 \mathrm{~A}$ cells were cultured as described in Materials and Methods. Moxestrol $(50 \mathrm{nM})$ was added for $24 \mathrm{~h}$, and cells were withdrawn from hormone (time zero). ApoII mRNA was analyzed by RNA probeexcess solution hybridization. (A) $\mathrm{CHX}(2.5 \mu \mathrm{g} / \mathrm{ml})$ was added $8 \mathrm{~h}$ after withdrawal. Cells were harvested at the indicated times for control (filled circles) and CHX-treated (open circles) samples. (B) Puromycin $(100 \mu \mathrm{g} / \mathrm{ml})$ was added $8 \mathrm{~h}$ after withdrawal. Cells were harvested at the indicated times for control (filled circles) and puromycin-treated (open circles) samples. Each point represents the mean \pm standard deviation of three replicate samples. Note that for small standard deviations, error bars are indistinguishable from datum points.

increase or decrease the half-lives of many mRNAs (70). The inhibitors CHX, which blocks chain elongation $(28,35,58)$, and puromycin, which causes premature chain termination (49, 50,62 ), were used to determine the effects of inhibiting protein synthesis on apoII mRNA turnover in $\mathrm{LMH} / 2 \mathrm{~A}$ cells. For these experiments, inhibitors were added $8 \mathrm{~h}$ after hormone withdrawal at concentrations sufficient to inhibit protein synthesis by $>90 \%$. As shown in Fig. 4A, treatment of cells with CHX superinduced apoII mRNA levels well above the levels observed in both samples withdrawn from hormone for $8 \mathrm{~h}$ (the time of CHX addition) and moxestrol-induced samples (time zero). Treatment of cells with puromycin had a similar effect on apoII mRNA (Fig. 4B). This superinduction could reflect either an apparent induction due to decreased levels of total cellular (primarily ribosomal) RNA or an actual induction due to increased apoII transcriptional activity in the absence of hormone. To test the first hypothesis, cells were induced with moxestrol and treated with or without $\mathrm{CHX}$ during hormone withdrawal. Total cellular RNA in extracts was assayed by the orcinol method, which measures ribose by specific reaction with orcinol after acid hydrolysis (39). No differences were observed for total cellular RNA from CHX-treated compared with withdrawn or moxestrol-treated cells (data not shown). Thus, the superinductive effect of $\mathrm{CHX}$ was not due to decreased levels of bulk cellular RNA.

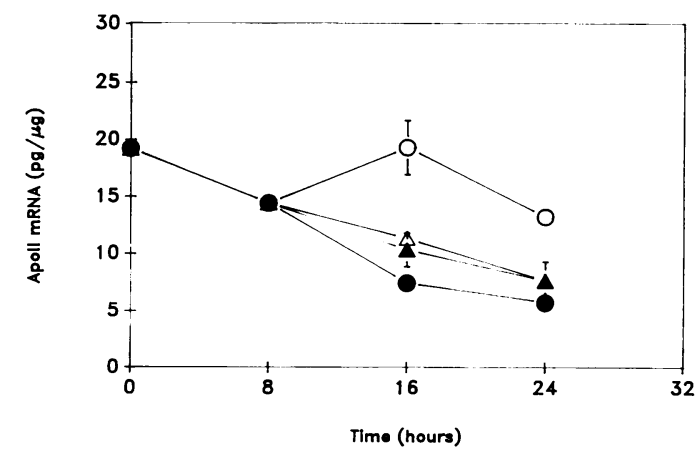

FIG. 5. Effect of DRB on CHX-induced superinduction of apoII mRNA. LMH/2A cells were cultured as described in Materials and Methods. Moxestrol $(50 \mathrm{nM})$ was added for $24 \mathrm{~h}$, and cells were withdrawn from hormone (time zero). CHX $(2.5 \mu \mathrm{g} / \mathrm{ml})$ and DRB (300 $\mu \mathrm{M})$ were added $8 \mathrm{~h}$ after withdrawal. Cells were harvested at the indicated times for control (filled circles), CHX-treated (open circles), DRB-treated (filled diamonds), and DRB-CHX-treated (open diamonds) samples. ApoII mRNA was analyzed by RNA probe-excess solution hybridization. Each point represents the mean \pm standard deviation of three replicate samples. Note that for small standard deviations, error bars are indistinguishable from datum points.

Several experiments were conducted to determine whether reactivation of transcription could account for superinduction of apoII mRNA following CHX treatment. First, the RNA synthesis inhibitor 5,6-dichlorobenzimidazole (DRB) was added simultaneously with $\mathrm{CHX}$ during hormone withdrawal. As shown in Fig. 5, apoII mRNA decayed slightly more slowly in samples treated with DRB alone compared with control samples. In the presence of both CHX and DRB, apoII mRNA decay was similar to that of DRB-treated samples. Thus, neither stabilization nor superinduction of apoII mRNA was evident. This result suggests that transcription is necessary for superinduction by $\mathrm{CHX}$. Furthermore, because apoII mRNA decayed normally in the presence of $\mathrm{CHX}$ when transcription was blocked, apoII mRNA does not appear to be stabilized by inhibition of protein synthesis.

To determine whether superinduction by $\mathrm{CHX}$ might require trace levels of hormone remaining after hormone withdrawal, cells were treated $8 \mathrm{~h}$ after hormone withdrawal with $\mathrm{CHX}$ in the presence of 4-hydroxytamoxifen. Control values at 0,8 , and $16 \mathrm{~h}$ after hormone withdrawal were $39.2 \pm 5.8,21.3$ \pm 3.9 , and $11.9 \pm 3.1 \mathrm{pg}$ of apoII mRNA per $\mu \mathrm{g}$, respectively. Sixteen-hour values for $\mathrm{CHX}$-treated and $\mathrm{CHX}-4$-hydroxytamoxifen-treated cells were $41.1 \pm 2.5$ and $51.6 \pm 8.9 \mathrm{pg}$ of apoII mRNA per $\mu \mathrm{g}$, respectively. 4-Hydroxytamoxifen did not inhibit superinduction by $\mathrm{CHX}$, which suggests that the hormone-liganded form of the estrogen receptor is not required for superinduction. Nevertheless, when $\mathrm{CHX}$ was added without prior hormone treatment, apoII mRNA was not induced $(1.4 \pm 1.3 \mathrm{pg} / \mu \mathrm{g})$ compared with the ethanol vehicle $(1.0 \pm$ $0.2 \mathrm{pg} / \mu \mathrm{g})$ or the moxestrol control $(32.6 \pm 1.3 \mathrm{pg} / \mu \mathrm{g})$. This finding indicates that hormone-induced events, perhaps assembly of the receptor-dependent transcription complex, were necessary for $\mathrm{CHX}$-induced transcriptional activation.

To test further for transcriptional activation of the apoII gene, apoII mRNA precursors were assayed by Northern blotting of $\mathrm{LMH} / 2 \mathrm{~A}$ nuclear RNA by using an intron A-specific DNA probe. Multiple intron A-containing splicing intermediates ranging up to $3.2 \mathrm{~kb}$ were evident (Fig. 6), as previously described (24). As shown in Fig. 6, apoII mRNA precursors were abundant in moxestrol-induced samples (lane 
A

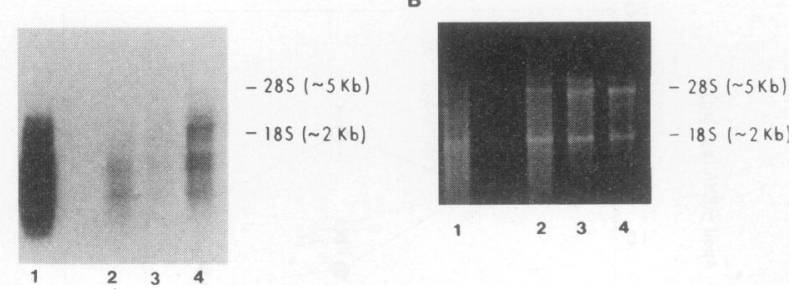

FIG. 6. Effect of CHX on apolI nuclear mRNA precursors. $\mathrm{LMH} / 2 \mathrm{~A}$ cells were cultured as described in Materials and Methods. Moxestrol $(50 \mathrm{nM})$ was added for $24 \mathrm{~h}$, and cells were withdrawn from hormone. CHX $(2.5 \mu \mathrm{g} / \mathrm{ml})$ was added $8 \mathrm{~h}$ after withdrawal. Cells were harvested, and nuclear RNA was isolated. Each lane contains $10 \mu \mathrm{g}$ of nuclear RNA. (A) Autoradiogram of Northern blot hybridized with an intron A-specific BstEII-EcoRI fragment of the apoII genomic clone pApo107. (B) Ethidium bromide-stained gel. Lanes: 1, moxestrolinduced cells; 2, moxestrol-induced cells, withdrawn for $8 \mathrm{~h} ; 3$, moxestrol-induced cells, withdrawn for $21 \mathrm{~h} ; 4$, moxestrol-induced cells, withdrawn for 21 , with CHX added $8 \mathrm{~h}$ after withdrawal. Positions of migration of $18 \mathrm{~S}$ and $28 \mathrm{~S}$ ribosomal bands and approximate molecular sizes are indicated.

1), markedly reduced in samples from cells withdrawn from hormone for $8 \mathrm{~h}$ (lane 2), and barely detectable in cells withdrawn from hormone for $21 \mathrm{~h}$ (lane 3 ). However, nuclear precursors were increased in cells withdrawn from hormone for $8 \mathrm{~h}$ and then treated with $\mathrm{CHX}$ for $13 \mathrm{~h}$ (lane 4), suggesting that apoII transcription was reactivated when $\mathrm{CHX}$ was added $8 \mathrm{~h}$ after hormone withdrawal.

Nuclear run-on assays for apoII gene transcription were conducted to confirm this point. Figure 7 shows that apoII gene transcription was higher in moxestrol-induced cells than in cells treated with the ethanol vehicle (lane 2 versus lane 1 ) and was markedly decreased in cells withdrawn from hormone for 8 or $15 \mathrm{~h}$ (lanes 3 and 4 ). However, apoII transcription was increased in cells withdrawn from hormone for $8 \mathrm{~h}$ and then treated with $\mathrm{CHX}$ for $7 \mathrm{~h}$ (lane 5 versus lane 4). Furthermore, in comparison with the chicken $\beta$-actin gene, the effect of $\mathrm{CHX}$ appears to be selective for the apoII gene. We have also confirmed in another run-on experiment that transcription of the apoII gene is increased by CHX selectively in comparison with either the transferrin or GAPDH gene (data not shown).

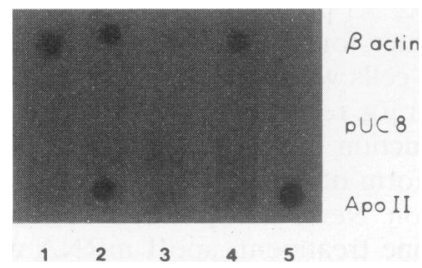

FIG. 7. Effect of $\mathrm{CHX}$ on apoII gene transcription. $\mathrm{LMH} / 2 \mathrm{~A}$ cells were cultured in T-75 flasks as described in Materials and Methods. Moxestrol $(50 \mathrm{nM})$ was added for $24 \mathrm{~h}$. Cells were withdrawn from hormone, and $\mathrm{CHX}(2.5 \mu \mathrm{g} / \mathrm{ml})$ was added $8 \mathrm{~h}$ later. Samples were harvested 0,8 , and $15 \mathrm{~h}$ following hormone withdrawal. Nuclei were isolated, and run-on transcription assays were conducted as described in Materials and Methods. Lanes: 1, ethanol-treated cells; 2, moxestrol-induced cells; 3 , moxestrol-induced cells, withdrawn for $8 \mathrm{~h} ; 4$, moxestrol-induced cells, withdrawn for $15 \mathrm{~h} ; 5$, moxestrol-induced cells, withdrawn for $15 \mathrm{~h}$, with $\mathrm{CHX}$ added $8 \mathrm{~h}$ after withdrawal. Dot blots contained $5 \mu \mathrm{g}$ of the indicated plasmid DNA, and $3.0 \times 10^{6} \mathrm{cpm}$ of labeled RNA from each transcription reaction was used for hybridization.
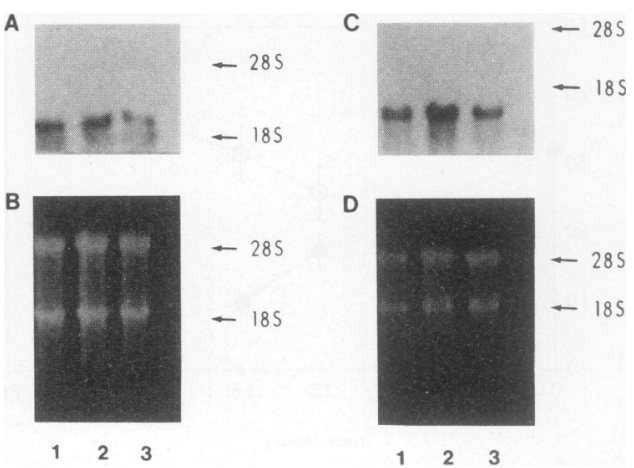

FIG. 8. Effects of CHX on transferrin and GAPDH mRNAs. LMH/2A cells were cultured as described in Materials and Methods. Moxestrol $(50 \mathrm{nM})$ was added for $24 \mathrm{~h}$, and cells were withdrawn from hormone for $8 \mathrm{~h}$ (lanes 1) or $21 \mathrm{~h}$ (lanes 2 and 3$)$. CHX $(2.5 \mu \mathrm{g} / \mathrm{ml})$ was added $8 \mathrm{~h}$ after withdrawal (lanes 3 ). Cells were harvested, and cytoplasmic RNA was isolated. Each lane contains $10 \mu \mathrm{g}$ of cytoplasmic RNA. (A) Northern blot probed for transferrin mRNA, using a 500-bp Bam HI fragment of pCon64; (B) ethidium bromide-stained gel used in panel $\mathrm{A} ;(\mathrm{C})$ blot probed for GAPDH mRNA, using an 1,100-bp PstI fragment of pGAD28; (D) ethidium bromide-stained gel used in panel C. Positions of migration of $18 \mathrm{~S}$ and $28 \mathrm{~S}$ ribosomal bands are indicated.

Puromycin was also found to increase apoII gene transcription when added $8 \mathrm{~h}$ after hormone withdrawal (data not shown). These findings confirmed that the protein synthesis inhibitors $\mathrm{CHX}$ and puromycin reactivated apoII transcription following hormone withdrawal. We also examined the steady-state levels of transferrin and GAPDH mRNAs by Northern blot analysis. Neither transferrin mRNA (Fig. 8A) nor GAPDH mRNA (Fig. 8B) was increased in cells treated with $\mathrm{CHX}$ following induction and withdrawal from moxestrol. Thus, rather than being a general response of transcriptionally active genes, superinduction appears to be selective for the apoII gene.

This ability of CHX to reactivate transcription suggests that a suppressed yet functional transcription complex was present on the apoII promoter following hormone withdrawal. The observation that two distinct translation-inhibiting drugs superinduce apoII mRNA suggests that a labile protein, rather than the drug itself, is responsible for the effect. If such a repressor normally is involved in blocking transcription following hormone withdrawal, then resynthesis of the repressor and reversal of superinduction should occur upon removal of $\mathrm{CHX}$ from cells. To test this hypothesis, $\mathrm{CHX}$ was removed from LMH/2A cells following $7 \mathrm{~h}$ of treatment. As shown in Fig. 9, apoII mRNA superinduction was blocked and apoII mRNA levels decreased upon removal of $\mathrm{CHX}$ for $9 \mathrm{~h}$. This result supports the idea that a repressor protein is involved in the normal transcriptional regulation of the apoII gene.

To determine whether $\mathrm{CHX}$ could superinduce apoII mRNA at later times following hormone withdrawal, cells were treated with moxestrol, withdrawn from hormone, and treated with $\mathrm{CHX}$ at 24 and $40 \mathrm{~h}$ following hormone withdrawal. As shown in Table 1, CHX was able to superinduce apoII mRNA at $24 \mathrm{~h}$ following hormone withdrawal, but the response was diminished at $40 \mathrm{~h}$. These data indicate that the capacity to reactivate apoII gene transcription following hormone withdrawal is a transient phenomenon.

The possibility of a repressor of apoII gene transcription raises the question of whether hormonal induction of transcription fully overcomes repression. The experiment shown in Fig. 10 was conducted to compare induction by moxestrol 


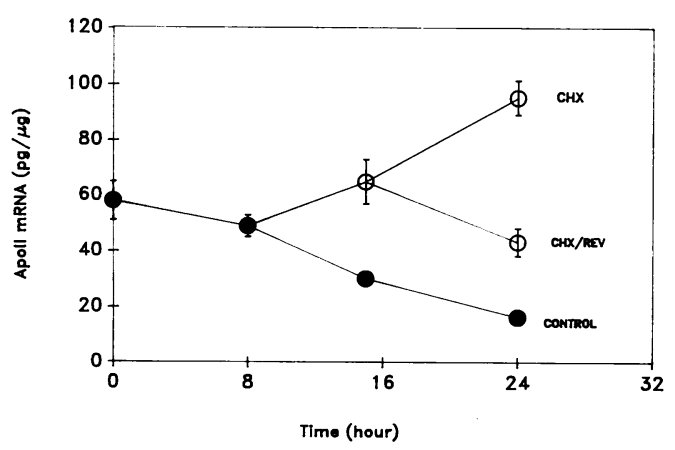

FIG. 9. Reversal of cycloheximide-induced superinduction of apoII mRNA. $\mathrm{LMH} / 2 \mathrm{~A}$ cells were cultured as described in Materials and Methods. Moxestrol $(50 \mathrm{nM})$ was added for $24 \mathrm{~h}$. Cells were withdrawn from hormone (time zero), and $\mathrm{CHX}(2.5 \mu \mathrm{g} / \mathrm{ml})$ was added $8 \mathrm{~h}$ after withdrawal. Medium was changed $15 \mathrm{~h}$ after withdrawal $(7 \mathrm{~h}$ after $\mathrm{CHX}$ addition) for two sets of $\mathrm{CHX}$-treated cells in order to remove inhibitor. CHX was then added back to one set of dishes (CHX); the second set was cultured without inhibitor (CHX/REV). Control cells were withdrawn from hormone in the absence of inhibitor. Cells were harvested at the indicated times, and apoII mRNA was analyzed by RNA probe-excess solution hybridization. Each point represents the mean \pm standard deviation of three replicate samples. Note that for small standard deviations, error bars are indistinguishable from datum points.

alone and in combination with $\mathrm{CHX}$. Reinduction of apoII mRNA following hormone withdrawal shows similar kinetics and magnitude for treatment with either moxestrol or CHX alone. However, the induction of apoII mRNA from 16 to 28 $\mathrm{h}$ after hormone withdrawal was completely additive for treatment with both moxestrol and CHX compared with either treatment alone. This result suggests that moxestrol and $\mathrm{CHX}$ elicit apoII mRNA induction via mechanistically distinct pathways and indicates that hormone binding to the receptor is not sufficient to induce transcription maximally.

\section{DISCUSSION}

Expression of apoII mRNA was augmented in LMH cells stably transfected with the chicken estrogen receptor as a result of increased receptor expression. In $\mathrm{LMH} / 2$ cell lines, which express estrogen receptor under the control of the Rous sarcoma virus promoter, both estrogen receptor and apoII mRNAs were increased markedly compared with levels in $\mathrm{LMH} / 1$ cell lines, which express receptor under control of the simian virus 40 promoter. ApoII mRNA levels in $\mathrm{LMH} / 2 \mathrm{~A}$ cells were increased more than 300 -fold compared with levels in the LMH parent cell line but were only 10 to $20 \%$ of the level observed in rooster liver. This lower level of induction in

TABLE 1. Superinduction of apoII mRNA 24 and $40 \mathrm{~h}$ after hormone withdrawal

\begin{tabular}{ccr}
\hline \multirow{2}{*}{$\begin{array}{c}\text { Time (h) after hormone } \\
\text { withdrawal }\end{array}$} & \multicolumn{2}{c}{ Mean apoll mRNA concn $(\mathrm{pg} / \mu \mathrm{g}) \pm \mathrm{SD}$} \\
\cline { 2 - 3 } & \multicolumn{1}{c}{ Control } & $\mathrm{CHX}^{b}$ \\
\hline 0 & $32.6 \pm 1.3$ & \\
24 & $7.0 \pm 0.4$ & \\
40 & $5.3 \pm 0.6$ & $12.6 \pm 0.5$ \\
56 & $2.7 \pm 0.2$ & $5.8 \pm 0.6$ \\
\hline
\end{tabular}

a Time zero reflects the level after $24 \mathrm{~h}$ of induction with moxestrol.

${ }^{b} \mathrm{CHX}(2.5 \mu \mathrm{g} / \mathrm{ml})$ was added 24 or $40 \mathrm{~h}$ after withdrawal, and apoII mRNA was measured $16 \mathrm{~h}$ later for $40-$ and $56-\mathrm{h}$ time points, respectively.

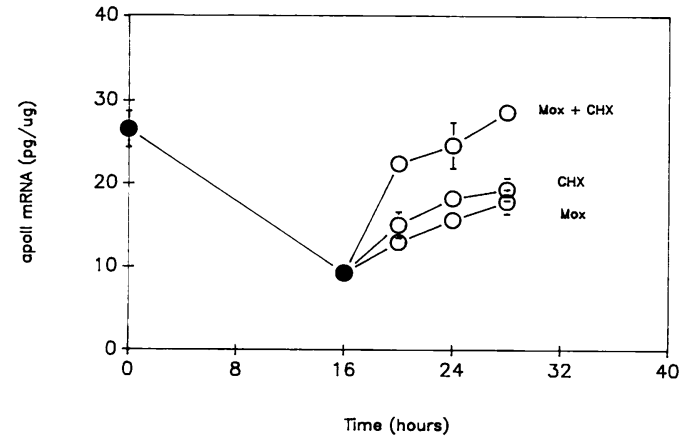

FIG. 10. Additive effect of $\mathrm{CHX}$ and moxestrol on induction of apoll mRNA. LMH/2A cells were cultured as described in Materials and Methods. Moxestrol (Mox; $50 \mathrm{nM}$ ) was added for $24 \mathrm{~h}$, and cells were withdrawn from hormone (time zero). CHX $(2.5 \mu \mathrm{g} / \mathrm{ml})$ and moxestrol $(50 \mathrm{nM})$ were added $16 \mathrm{~h}$ after hormone withdrawal. Samples were harvested 0 and $16 \mathrm{~h}$ after withdrawal (filled circles) and 4,8 , and $12 \mathrm{~h}$ after subsequent addition of hormone or inhibitor (open circles). ApolI mRNA was analyzed by RNA probe-excess solution hybridization. Each point represents the mean \pm standard deviation of three replicate samples. Note that for small standard deviations, error bars are indistinguishable from datum points.

the $\mathrm{LMH} / 2$ lines does not appear to reflect an inadequate concentration of estrogen receptor because the $\mathrm{LMH} / 2 \mathrm{~A}$ line has approximately sixfold more nuclear estrogen receptor than is found in rooster liver. The lower response could reflect the absence of another factor permissive for estrogen action. Alternatively, growing LMH cells may have higher levels of the putative repressor protein than nongrowing adult hepatocytes.

Availability of the $\mathrm{LMH} / 2 \mathrm{~A}$ cell line should allow detailed study of the mechanisms of apoII mRNA turnover. In $\mathrm{LMH} / 2 \mathrm{~A}$ cells, apoII mRNA half-life was approximately $8.4 \mathrm{~h}$ in the presence of the synthetic estrogen moxestrol and approximately 9 to $11 \mathrm{~h}$ during hormone withdrawal following a 24-h induction. These values are similar to those for rooster liver following induction with $17 \beta$-estradiol for $24 \mathrm{~h} \mathrm{(30)}$. In studies to be described elsewhere, we have also determined that the pattern of apoII mRNA degradation intermediates in $\mathrm{LMH} / 2 \mathrm{~A}$ cells $(56 \mathrm{a})$ is identical to that seen in rooster liver (8). The $\mathrm{LMH} / 2$ cell lines should prove useful for the further analysis of apoII mRNA turnover.

Because ongoing translation is required for the turnover of numerous mRNAs (70), we examined the effect of inhibiting protein synthesis on apoII mRNA degradation. Following hormone withdrawal, $\mathrm{CHX}$ and puromycin superinduced apoII mRNA but not GAPDH or transferrin mRNA. Because superinduction occurs with both $\mathrm{CHX}$ and puromycin, it is likely that the observed effects are due to the inhibition of protein synthesis rather than to unrelated effects of the inhibitors. The observed superinduction could have been attributable to increased apoII gene transcription or a combination of increased transcription and mRNA stabilization. Treatment of cells with $\mathrm{CHX}$ together with the transcription inhibitor DRB indicated that apoII mRNA stabilization by $\mathrm{CHX}$ was not involved in superinduction. This result suggests that apoII mRNA degradation does not require ongoing translation and that superinduction is a transcriptional event. Increased levels of apoII mRNA nuclear precursors and increased transcription in nuclear run-on assays confirmed that superinduction resulted from reactivation of apoII gene transcription. Superinduction was not a result of hormone-induced transcription of the apoII gene because the estrogen receptor antagonist 
4-hydroxytamoxifen did not prevent the effect. Nevertheless, prior induction with hormone was required for superinduction, perhaps to establish a competent transcriptional complex on the apolI promoter.

These findings indicate that at least two distinct events are necessary for the deactivation of estrogen receptor-mediated transcription of the apoII gene. The first event is removal of hormone: in the presence of ongoing translation, removal of hormone is sufficient to terminate expression of the gene. The second event is revealed in the presence of inhibitors of protein synthesis: superinduction by $\mathrm{CHX}$ or puromycin following hormone withdrawal suggests that deactivation of estrogen receptor-mediated transcription requires a labile protein whose concentration decreases when protein synthesis is inhibited. This labile protein could function at several levels in apoII gene transcription. First, the labile protein could be a repressor that interacts with the unligated estrogen receptor itself. Second, the labile protein could interact either with DNA elements distinct from the estrogen response elements or with other transcription factors that bind to the apoII promoter (4, $67)$. Third, a labile protein could be required in the reestablishment of a repressive chromatin configuration following hormone withdrawal. Although we cannot distinguish among these possibilities, several recent findings are relevant.

A yeast protein, SSN6, that represses the estrogen receptor has been identified recently (48). SSN6 blocks transactivation in yeast cells by the TAF1 domain of the human estrogen receptor. Furthermore, in a mutant yeast strain that lacks SSN6, basal transactivation by the TAF1 domain is increased compared with activity in wild-type cells. Thus, SSN6 appears to repress the hormone-independent activity of the TAF1 domain. These results raise the possibility of a similar repressor in avian and mammalian cells.

Several mammalian transcription factors have also been shown to repress transactivation by steroid receptors in transfection assays. In MCF-7 cells, overexpression of c-Fos and c-Jun was shown to inhibit estrogen receptor activity, and overexpression of receptor could abolish the repression by c-Fos (26). Similar findings have been reported with other steroid receptors. For example, the Jun-Fos heterodimer may repress vitamin $\mathrm{D}_{3}$ - and retinoic acid-induced transcription of the osteocalcin gene (55), and c-Fos and c-Jun may repress transcription by complexing with the glucocorticoid receptor $(37,54,72)$. Together, these findings suggest that a repressor may be a common participant in the regulation of gene expression by the estrogen receptor. However, the finding that CHX does not superinduce transcription of either the Xenopus vitellogenin gene (34) or the human pS2 gene (12) suggests that there may be a gene-specific component to superinduction that extends beyond the estrogen receptor itself.

With regard to alterations in chromatin, a number of studies have shown estrogen-dependent changes in DNase I-hypersensitive sites (42) and dimethyl sulfate-reactive sites (67) within $300 \mathrm{bp}$ upstream of the apoII transcription initiation site. These changes may result from binding of specific transcription factors, including the receptor $(4,67)$, but may also reflect changes in nucleosomal organization on the apoII promoter. A structural change in the chromatin organization of the mouse mammary tumor virus promoter occurs upon glucocorticoid treatment as a result of an altered interaction of promoter DNA with a specifically positioned nucleosome (52). This change appears to derepress the promoter by mediating access of transcription factors to their DNA binding sites (1). It is possible that the deactivation of receptor-mediated transcription may require reversal of such chromatin alterations. If similar events occur in the apoII promoter, reactivation of transcription by $\mathrm{CHX}$ might reflect the loss of a protein that is directly or indirectly involved in establishment of a repressive chromatin configuration.

Superinduction of message levels following treatment with protein synthesis inhibitors also has been reported for 9E3 mRNA (59), beta interferon mRNA (53), metallothionein-I mRNA, (47), adenovirus early gene products (25), and CYP1A1 mRNA (36). In the case of CYP1A1 mRNA (46), superinduction by $\mathrm{CHX}$ required a 20-nucleotide $C Y P 1 A 1$ gene promoter element that contained the core recognition sequence for the $\mathrm{Ah}$ receptor. However, $\mathrm{CHX}$-induced alterations were not observed in either in vitro gel shift or in vivo DNA methylation interference analyses, suggesting that a $\mathrm{CHX}$-sensitive factor was involved in a protein-protein interaction that repressed transcription of CYP1A1.

In the cases described above, superinduction by $\mathrm{CHX}$ reflects increased expression of genes that are actively transcribed. A unique feature of apoII superinduction is that $\mathrm{CHX}$ induces transcription up to $24 \mathrm{~h}$ following termination of transcription by hormone withdrawal but has little effect if added $40 \mathrm{~h}$ after hormone withdrawal. One explanation for this transiency is that a functional yet repressed transcription complex remains on the apoII promoter for a considerable time after removal of hormone before eventually dissociating. Another explanation is that an altered chromatin configuration necessary for apoII transcription is gradually lost following hormone withdrawal. In either case, reactivation of transcription by estrogen during this transient period following hormone withdrawal may be facilitated if it is not necessary to reestablish the complex of transcription factors or the altered chromatin configuration that occurs upon first exposure to the hormone. This model may be physiologically relevant because the egg-laying cycle and plasma estrogen concentration in the hen fluctuate with similar periodicities of 26 to $28 \mathrm{~h}$ (44). Transcription of the apoII gene would be expected to occur with a similar periodicity in response to plasma estrogens. Maintaining the apoII gene in a functional yet repressed mode when the estrogen concentration drops may facilitate reactivation of transcription when the estrogen concentration rises in the next cycle.

The present findings are consistent with the idea of a repressor acting to deactivate transcription of the apoII gene upon hormone withdrawal. In this model, $\mathrm{CHX}$ treatment leads to reactivation of transcription by blocking synthesis of the repressor. The data are also consistent with a more indirect role of CHX: CHX may lead to the loss not of a repressor but of a third component that is necessary for the regulation of repressor function. One implication of these findings is that loss or mutational inactivation of repressor function could lead to constitutive estrogen-independent expression of a gene that is normally under strict hormonal control. This may be relevant, for example, in the loss of growth control in breast cancer or in the progression to hormone-independent growth states. The $\mathrm{LMH} / 2$ cell lines should prove useful for the analysis of steps leading to deactivation of estrogen receptor-mediated transcription. These cell lines will also facilitate other studies of estrogen-regulated avian liver gene expression by providing a homologous cell line.

\section{ACKNOWLEDGMENTS}

Plasmids pApo107 and pRSVCEO were gifts of John Burch, plasmids pCon64 and pGAD28 were obtained from Marilyn Evans, and plasmid pCEO was a gift of P. Chambon. Excellent technical assistance was provided by Penelope Strockbine (D.L.W. laboratory) and Elizabeth Campbell Dwyer (C.B.L. laboratory). 
This work was supported by NIH grant DK 18171 (to D.L.W.) and MRC (Canada) grant MT 4880 (to C.B.L.). M.G.S. was supported by an American Heart Association postdoctoral fellowship and by $\mathrm{NIH}$ postdoctoral training grant IT32DK07521.

\section{REFERENCES}

1. Archer, T. K., M. G. Cordingley, R. G. Wolford, and G. L. Hager. 1991. Transcription factor access is mediated by accurately positioned nucleosomes on the mouse mammary tumor virus promoter. Mol. Cell. Biol. 11:688-698.

2. Bakker, O., A. T. Das, and G. AB. 1988. Protein-DNA interactions in vitro with $5^{\prime}$-flanking DNA fragments from the chicken vitellogenin gene. J. Steroid Biochem. 30:209-212.

3. Bakker, O., J. N. J. Philipsen, B. C. Hennis, and G. AB. 1988. Estrogen-inducible binding of a nuclear factor to the vitellogenin upstream region. Mol. Cell. Biol. 8:4557-4560.

4. Beekman, J. M., J. Wijnholds, I. J. Schippers, W. Pot, M. Gruber, and G. AB. 1991. Regulatory elements and DNA-binding proteins mediating transcription from the chicken very-low-density apolipoprotein II gene. Nucleic Acids Res. 19:5371-5377.

5. Bergink, E. W., R. A. Wallace, J. A. Van de Berg, E. S. Bos, M. Gruber, and G. AB. 1974. Estrogen-induced synthesis of yolk proteins in roosters. Am. Zool. 14:1177-1193.

6. Berkowitz, E. A., and M. I. Evans. 1992. Functional analysis of regulatory regions upstream and in the first intron of the estrogenresponsive chicken very low density apolipoprotein II gene. J. Biol. Chem. 267:7134-7138.

7. Berlin, C. M., and R. T. Schimke. 1965. Influence of turnover rates on the responses of enzymes to cortisone. Mol. Pharmacol. 1:149-156.

8. Binder, R., S.-P. L. Hwang, R. Ratnasabapathy, and D. L. Williams. 1989. Degradation of apolipoprotein II mRNA occurs via endonucleolytic cleavage at $5^{\prime}$-AAU-3'/5'-UAA-3' elements in single-stranded loop domains of the $3^{\prime}$-noncoding region. J. Biol. Chem. 264:16910-16918.

9. Binder, R., C. C. MacDonald, J. B. E. Burch, C. B. Lazier, and D. L. Williams. 1990. Expression of endogenous and transfected apolipoprotein II and vitellogenin II genes in an estrogen responsive chicken liver cell line. Mol. Endocrinol. 4:201-208.

10. Blue, M.-L. 1981. Biosynthesis of major avian and human apoproteins. Ph.D. dissertation. State University of New York at Stony Brook, Stony Brook.

11. Borgna, J.-L., and H. Rochefort. 1981. Hydroxylated metabolites of tamoxifen are formed in vivo and bound to estrogen receptor in target tissues. J. Biol. Chem. 256:859-868.

12. Brown, A. M. C., J.-M. Jeltsch, M. Roberts, and P. Chambon. 1984. Activation of $p S 2$ gene transcription is a primary response to estrogen in the human breast cancer cell line MCF-7. Proc. Natl. Acad. Sci. USA 81:6344-6348.

12a.Burch, J. Personal communication.

13. Burch, J. B. E., M. I. Evans, T. M. Friedman, and P. J. O'Malley. 1988. Two functional estrogen response elements are located upstream of the major chicken vitellogenin gene. Mol. Cell. Biol. 8:1123-1131.

14. Burch, J. B. E., and A. H. Fischer. 1990. Chromatin studies reveal that an ERE is located far upstream of a vitellogenin gene and that a distal tissue-specific hypersensitive site is conserved for two coordinately regulated vitellogenin genes. Nucleic Acids Res. 18:4157-4165.

15. Burch, J. B. E., and H. Weintraub. 1983. Temporal order of chromatin structural changes associated with activation of the major chicken vitellogenin gene. Cell 33:65-76.

16. Bush, L., T. J. McGahan, and H. B. White III. 1988. Purification and characterization of biotin-binding protein II from chicken oocytes. Biochem. J. 256:797-805.

17. Capony, F., and D. L. Williams. 1980. Apolipoprotein B of avian very low density lipoprotein: characteristics of its regulation in the nonstimulated and estrogen-stimulated rooster. Biochemistry 19: 2219-2226.

18. Chan, L., R. L. Jackson, B. W. O'Malley, and A. R. Means. 1976. Synthesis of very low density lipoproteins in the cockerel. J. Clin. Invest. 58:368-379.

19. Chen, C., and H. Okayama. 1987. High-efficiency transformation of mammalian cells by plasma DNA. Mol. Cell. Biol. 7:2745-2752.

20. Chirgwin, J. M., A. E. Przybyla, R. J. MacDonald, and W. J. Rutter. 1979. Isolation of biologically active ribonucleic acid from sources enriched in ribonuclease. Biochemistry 18:5294-5299.

21. Chomczynski, P., and N. Sacchi. 1987. Single-step method of RNA isolation by acid guanidinium thiocyanate-phenol-chloroform extraction. Anal. Biochem. 162:156-159.

22. Cleveland, D. W., M. A. Lopata, R. J. MacDonald, N. J. Cowan, W. J. Rutter, and M. W. Kirschner. 1980. Number and evolutionary conservation of $\alpha$ - and $\beta$-tubulin and cytoplasmic $\beta$ - and $\tau$-actin genes using specific cloned cDNA probes. Cell 20:95-105.

23. Cochet, M., F. Perrin, F. Gannon, A. Krust, P. Chambon, G. S. McKnight, D. C. Lee, K. E. Mayo, and R. Palmiter. 1979. Cloning of an almost full-length chicken conalbumin double-stranded cDNA. Nucleic Acids Res. 6:2435-2452.

24. Colgan, V., A. Elbrecht, P. Goldman, C. B. Lazier, and R. Deeley. 1982. The avian apoprotein II very low density lipoprotein gene. Methylation patterns of $5^{\prime}$ and $3^{\prime}$ flanking regions during development and following induction by estrogen. J. Biol. Chem. 257:14453-14460.

25. Cross, F. R., and J. E. Darnell, Jr. 1983. Cycloheximide stimulates early adenovirus transcription if early gene expression is allowed before treatment. J. Virol. 45:683-692.

26. Doucas, V., G. Spyrou, and M. Yaniv. 1991. Unregulated expression of c-Jun or c-Fos proteins but not Jun D inhibits oestrogen receptor activity in human breast cancer derived cells. EMBO J. 10:2237-2245.

27. Dugaiczyk, A., J. A. Haron, E. M. Stone, O. E. Dennison, K. N. Rothblum, and R. J. Schwartz. 1983. Cloning and sequencing of a deoxyribonucleic acid copy of glyceraldehyde-3-phosphate dehydrogenase messenger ribonucleic acid isolated from chicken muscle. Biochemistry 22:1605-1613.

28. Fan, H., and S. Penman. 1970. Regulation of protein synthesis in mammalian cells. Inhibition of protein synthesis at the level of initiation during mitosis. J. Mol. Biol. 50:655-670.

29. Gilman, M. 1987. Preparation of cytoplasmic RNA from tissue culture cells, p. 4.1.2-4.1.6. In F. M. Ausubel, R. Brent, R. E. Kingston, D. D. Moore, J. G. Seidman, J. A. Smith, and K. Struhl (ed.), Current protocols in molecular biology, vol. 1. Greene Publishing Associates and Wiley Interscience, New York.

30. Gordon, D. A., G. S. Shelness, M. Nicosia, and D. L. Williams. 1988. Estrogen-induced destabilization of yolk precursor protein mRNAs in avian liver. J. Biol. Chem. 263:2625-2631.

31. Gorman, C., R. Padmanabhan, and B. H. Howard. 1983. High efficiency DNA-mediated transformation of primate cells. Science 221:551-553.

32. Green, S., P. Walter, V. Kumar, A. Krust, J.-M. Bornert, P. Argos, and P. Chambon. 1986. Human oestrogen receptor cDNA: sequence, expression and homology to v-erb-A. Nature (London) 320:134-139.

33. Greenberg, M. E., and T. P. Bender. 1987. Identification of newly transcribed RNA, p. 4.10.1-4.10.9. In F. M. Ausubel, R. Brent, R. E. Kingston, D. D. Moore, J. G. Seidman, J. A. Smith, and K. Struhl (ed.), Current protocols in molecular biology, vol. 1. Greene Publishing Associates and Wiley Interscience, New York.

34. Hayward, M. A., M. L. Brock, and D. J. Shapiro. 1982. Activation of vitellogenin gene transcription is a direct response to estrogen in Xenopus laevis liver. Nucleic Acids Res. 10:8273-8284.

35. Hogan, B. L. M. 1969. The effect of inhibitors of protein synthesis on the level of ribosomal subunits in ascites cells. Biochim. Biophys. Acta 182:264-266.

36. Israel, D. I., M. G. Estolano, D. R. Galeazzi, and J. P. Whitlock, Jr. 1985. Superinduction of cytochrome $P_{1}-450$ gene transcription by inhibition of protein synthesis in wild type and variant mouse hepatoma cells. J. Biol. Chem. 260:5648-5653.

37. Jonat, C., H. J. Rahmsdorf, K.-K. Park, A. C. B. Cato, S. Gebel, H. Ponta, and P. Herrlich. 1990. Antitumor promotion and antiinflammation: down-modulation of AP-1 (Fos/Jun) activity by glucocorticoid hormone. Cell 62:1189-1204.

38. Jost, J.-P., H.-P. Saluz, and A. Pawlak. 1991. Estradiol down regulates the binding activity of an avian vitellogenin gene repressor (MDBP-2) and triggers a gradual demethylation of the $\mathrm{mCpG}$ pair of its DNA binding site. Nucleic Acids Res. 19:5771-5775. 
39. Kabat, E. A., and M. M. Mayer. 1961. Experimental immunochemistry. Charles C Thomas, Springfield, Ill.

40. Katzenellenbogen, J. A., K. E. Carlson, D. F. Heiman, D. W. Robertson, L. L. Wei, and B. S. Katzenellenbogen. 1983. Efficient and highly selective covalent labeling of the estrogen receptor with $\left[{ }^{3} \mathrm{H}\right]$ tamoxifen aziridine. J. Biol. Chem. 258:3487-3495.

41. Kawaguchi, T., K. Nomura, Y. Hirayama, and T. Kitagawa. 1987. Establishment and characterization of a chicken hepatocellular carcinoma cell line LMH. Cancer Res. 47:4460-4464.

42. Kok, K., L. Snippe, G. Ab, and M. Gruber. 1985. Nucleasehypersensitive sites in chromatin of the estrogen-inductible apoVLDL II gene of chicken. Nucleic Acids Res. 13:5189-5202.

43. Krust, A., S. Green, P. Argos, V. Kumar, P. Walter, J.-M. Bornert, and P. Chambon. 1986. The chicken oestrogen receptor sequence: homology with v-erb-A and the human oestrogen and glucocorticoid receptors. EMBO J. 5:891-897.

44. Laguë, P. C., A. van Tienhoven, and F. J. Cunningham. 1975. Concentrations of estrogens, progesterone and LH during the ovulatory cycle of the laying chicken [Gallus domesticus]. Biol. Reprod. 12:590-598.

45. Lazier, C. B. 1978. Ontogeny of the vitellogenic response to oestradiol and of the soluble nuclear oestrogen receptor in embryonic-chick liver. Biochem. J. 174:143-152.

46. Lusska, A., L. Wu, and J. P. Whitlock, Jr. 1992. Superinduction of CYP1A1 transcription by cycloheximide. Role of the DNA binding site for the liganded Ah receptor. J. Biol. Chem. 267:15146-15151.

47. Mayo, K. E., and R. D. Palmiter. 1981. Glucocorticoid regulation of metallothionein-I mRNA synthesis in cultured mouse cells. J. Biol. Chem. 256:2621-2624.

48. McDonnell, D. P., E. Vegeto, and B. W. O'Malley. 1992. Identification of a negative regulatory function for steroid receptors. Proc. Natl. Acad. Sci. USA 89:10563-10567.

49. Morris, A., and R. Sweet. 1961. Release of soluble proteins from reticulocyte ribosomes. Biochim. Biophys. Acta 47:415-416.

50. Pestka, S. 1971. The use of inhibitors in studies of protein synthesis. Methods Enzymol. 30:261-282.

51. Raynaud, J.-P., M.-M. Bouton, D. Gallet-Bourquin, D. Philibert, C. Tournemine, and G. Azadian-Boulanger. 1973. Comparative study of estrogen action. Mol. Pharmacol. 9:520-533.

52. Richard-Foy, H., and G. L. Hager. 1987. Sequence-specific positioning of nucleosomes over the steroid-inducible MMTV promoter. EMBO J. 6:2321-2328.

53. Ringold, G. M., B. Dieckmann, J. L. Vannice, M. Trahey, and F. McCormick. 1984. Inhibition of protein synthesis stimulates the transcription of human $\beta$-interferon genes in Chinese hamster ovary cells. Proc. Natl. Acad. Sci. USA 81:3964-3968.

54. Schüle, R., P. Rangarajan, S. Kliewer, L. J. Ransone, J. Bolado, N. Yang, I. M. Verma, and R. M. Evans. 1990. Functional antagonism between oncoprotein c-Jun and the glucocorticoid receptor. Cell 62:1217-1226.

55. Schüle, R., K. Umesono, D. J. Mangelsdorf, J. Bolado, J. W. Pike, and R. M. Evans. 1990. Jun-Fos and receptors for vitamins A and $\mathrm{D}$ recognize a common response element in the human osteocalcin gene. Cell 61:497-504.

56. Seal, S. N., D. L. Davis, and J. B. E. Burch. 1991. Mutational studies reveal a complex set of positive and negative control elements within the chicken vitellogenin II promoter. Mol. Cell.
Biol. 11:2704-2717.

56a.Sensel, M. G., and D. L. Williams. Unpublished data.

57. Shelness, G. S., and D. L. Williams. 1984. Apolipoprotein II messenger RNA: transcriptional and splicing heterogeneity yields six 5'-untranslated leader sequences. J. Biol. Chem. 259:99299935.

58. Stanners, C. P. 1966. The effect of cycloheximide on polyribosomes from hamster cells. Biochem. Biophys. Res. Commun. 24:758-764.

59. Sugano, S., M. Y. Stoeckle, and H. Hanafusa. 1987. Transformation by Rous sarcoma virus induces a novel gene with homology to a mitogenic platelet protein. Cell 49:321-328.

60. Sutherland, R., J. Mester, and E.-E. Baulieu. 1977. Tamoxifen is a potent 'pure' anti-oestrogen in chick oviduct. Nature (London) 267:434-435.

61. Sutherland, R. L. 1981. Estrogen antagonists in chick oviduct: antagonist activity of eight synthetic triphenylethylene derivatives and their interactions with cytoplasmic and nuclear estrogen receptors. Endocrinology 109:2061-2068.

62. Traut, R. R., and R. E. Monroe. 1964 . The puromycin reaction and its relation to protein synthesis. J. Mol. Biol. 10:63-72.

63. Wang, S.-Y., D. E. Smith, and D. L. Williams. 1983. Purification of avian vitellogenin III: comparison with vitellogenins I and II. Biochemistry 22:6206-6212.

64. Wang, S.-Y., and D. L. Williams. 1980. Identification, purification, and characterization of two distinct avian vitellogenins. Biochemistry 19:1557-1563.

65. Watson, G., R. A. Davey, C. Labarca, and K. Paigen. 1981. Genetic determination of kinetic parameters in $\beta$-glucurodinase induction by androgen. J. Biol. Chem. 256:3005-3011.

66. White, H. B., III, and A. H. Merrill, Jr. 1988. Riboflavin-binding proteins. Annu. Rev. Nutr. 8:279-299.

67. Wijnholds, J., J. N. J. Philipsen, and G. AB. 1988. Tissue-specific and steroid-dependent interaction of transcription factors with the oestrogen-inducible apoVLDL II promoter in vivo. EMBO J. 7:2757-2763.

68. Wilks, A., M. Seldran, and J.-P. Jost. 1984. An estrogen-dependent demethylation at the $5^{\prime}$ end of the chicken vitellogenin gene is independent of DNA synthesis. Nucleic Acids Res. 12:11641177.

69. Williams, D. L., T. C. Newman, G. S. Shelness, and D. A. Gordon. 1986. Measurement of apolipoprotein mRNA by DNA-excess solution hybridization with single stranded probes. Methods Enzymol. 128:671-689.

70. Williams, D. L., M. Sensel, M. McTigue, and R. Binder. 1993. Hormonal and developmental regulation of mRNA turnover, p. 161-197. In G. Brawerman and J. Belasco (ed.), Control of mRNA stability. Academic Press, San Diego, Calif.

71. Wiskocil, R., P. Bensky, W. Dower, R. F. Goldberger, J. I. Gordon, and R. G. Deeley. 1980. Coordinate regulation of two estrogendependent genes in avian liver. Proc. Natl. Acad. Sci. USA 77:4474-4478.

72. Yang-Yen, H.-F., J.-C. Chambard, Y.-L. Sun, T. Smeal, T. J. Schmidt, J. Drouin, and M. Karin. 1990. Transcriptional interference between c-Jun and the glucocorticoid receptor: mutual inhibition of DNA binding due to direct protein-protein interaction. Cell 62:1205-1215. 